\title{
Blood-based molecular biomarkers for Alzheimer's disease
}

\author{
Henrik Zetterberg ${ }^{1,2,3,4^{*}}$ (D) and Samantha C. Burnham ${ }^{5,6^{*}}$
}

\begin{abstract}
A major barrier to the effective conduct of clinical trials of new drug candidates against Alzheimer's disease (AD) and to identifying patients for receiving future disease-modifying treatments is the limited capacity of the current health system to find and diagnose patients with early AD pathology. This may be related in part to the limited capacity of the current health systems to select those people likely to have AD pathology in order to confirm the diagnosis with available cerebrospinal fluid and imaging biomarkers at memory clinics. In the current narrative review, we summarize the literature on candidate blood tests for AD that could be implemented in primary care settings and used for the effective identification of individuals at increased risk of AD pathology, who could be referred for potential inclusion in clinical trials or future approved treatments following additional testing. We give an updated account of blood-based candidate biomarkers and biomarker panels for AD-related brain changes. Our analysis centres on biomarker candidates that have been replicated in more than one study and discusses the need of further studies to achieve the goal of a primary care-based screening algorithm for AD.
\end{abstract}

Keywords: Alzheimer's disease, Serum, Plasma, Blood, Biomarkers, Amyloid, Tau

\section{Introduction}

Alzheimer's disease $(\mathrm{AD})$ is characterized by the accumulation of extracellular amyloid $\beta(A \beta)$ plaques, intraneuronal inclusions (neurofibrillary tangles) composed of truncated and phosphorylated forms of the microtubule-stabilizing protein tau, dystrophic neurites, loss of synapses and neurons, and a prominent gliosis that involves changes in the morphology and function of microglia and astrocytes [1]. Currently, we have validated biomarkers for amyloid pathology (A $\beta$ positron emission tomography $[\mathrm{PET}]$ and the ratio of 42 over 40 amino acid long $A \beta$ cerebrospinal fluid [CSF A $342 / A \beta 40]$ ] [2], as well as tau dysfunction and aggregation (cerebrospinal fluid [CSF] total or phosphorylated tau and tau PET) [3]. CSF and PET examinations are, however, far from standard tests in general practice and, given the high prevalence of the disease, alternatives such as blood-based biomarkers would represent a significant development, even as screening tools to determine who

\footnotetext{
* Correspondence: henrik.zetterberg@clinchem.gu.se;

Samantha.Burnham@csiro.au

${ }^{1}$ Department of Psychiatry and Neurochemistry, Institute of Neuroscience and Physiology, he Sahlgrenska Academy at the University of Gothenburg, Mölndal, Sweden

${ }^{5} \mathrm{CSIRO}$ Health and Biosecurity, Parkville, Victoria 3052, Australia

Full list of author information is available at the end of the article
}

should be referred to a memory clinic for specific testing. Here, we review recent developments in the field of blood biomarkers for $\mathrm{AD}$ and discuss the results in the context of the quests to improve diagnostic algorithms and facilitate clinical trials of novel candidate drugs.

\section{Blood biomarkers - general considerations}

Measuring biomarkers for brain diseases in the blood poses a number of challenges that demand sensitive and specific assays and careful validation work. Brain-derived biomarkers are typically present at relatively low concentrations in the blood because of the blood-brain barrier preventing free passage of molecules between the CNS and blood compartments. In addition, some of the biomarkers related to $\mathrm{AD}$ pathology are expressed in non-cerebral tissues, which may confound their measurement in the blood. Further, in blood, there may be heterophilic antibodies (endogenous antibodies that react with the antibodies of the immunochemical test to measure the biomarker), which may give falsely high or low results. These types of antibodies are much less of a problem in CSF where antibody levels are much lower. Finally, the analyte of interest may undergo proteolytic degradation by various proteases in plasma. Below, we

(c) The Author(s). 2019 Open Access This article is distributed under the terms of the Creative Commons Attribution 4.0 International License (http://creativecommons.org/licenses/by/4.0/), which permits unrestricted use, distribution, and 
discuss recent developments of biomarkers for the pathological processes involved in AD. We discuss biomarker tests that are directed against a single pathological change and biomarker panels that may reflect tissue reactions to such changes.

\section{Targeted blood-based biomarkers Plasma $A \beta$}

Early results on plasma $A \beta$, described in the AlzBiomarker database (https://www.alzforum.org/alzbiomarker), revealed no consistent change in either plasma $A \beta 42$ or $A \beta 40$ in $A D$ [4]. This result was most likely due to assay-related difficulties; plasma $\mathrm{A} \beta$ measurements may be influenced by matrix effects (mainly other plasma proteins binding $A \beta$ ) and the analytical sensitivities of the first assays did not allow for diluting away such matrix effects. In 2011, an ultrasensitive Single molecule array (Simoa) assay for A $\beta 42$ was published [5]. A correlation of plasma with CSF $A \beta 42$ emerged and the improved analytical sensitivity clarified that the ratio of $A \beta 42$ to $A \beta 40$ in plasma was reduced in amyloid PET-positive individuals in a manner similar to CSF $A \beta 42 / A \beta 40$, although with less marked separation [6, 7]. A few years ago, reliable immunoprecipitation mass spectrometry (IP-MS)-based assays for $A \beta 40$ and $A \beta 42$ were described showing a decrease in the plasma $A \beta 42$ / A $\beta 40$ ratio (similar to the CSF test) with around $90 \%$ diagnostic accuracy $[8,9]$. These are highly promising developments that have spurred several method comparison and standardization studies that are just about to start. These new assay formats do not solve the confounding problem with non-cerebral expression of $A \beta$, e.g., in blood platelets [10], which affects the specificity of the test for cerebral $A \beta$ plaques, but still represent an important step forward.

\section{Plasma tau}

In the dementia stage of $\mathrm{AD}$, plasma tau concentrations, measured using ultrasensitive assays, are increased compared with cognitively normal control individuals, but not as clearly as in CSF [11], which is a well-replicated finding [4]. There is little clarity on the application of these findings to intermediary participants in the mild cognitive impairment (MCI) stage of the disease with reports being less clear [12]. Nevertheless, in a recent paper, Mielke and colleagues examined the relationship of plasma T-tau concentration, determined by Simoa, with cognitive decline in 458 participants from the Mayo Clinic Study on Aging and found high plasma T-tau associated with faster clinical disease progression [13]. Another study prospective cohort study used data from the US community-based Framingham Heart Study with replication in the Memento study, and found that plasma T-tau was strongly associated with incident $\mathrm{AD}$ dementia [14]. Mielke et al. also developed an assay for tau phosphorylated at amino acid 181 [15]. Plasma P-tau concentration, measured using this assay, was associated with both $\mathrm{A} \beta$ and tau PET, as well as with other $\mathrm{AD}$-associated phenotypes [15]; these associations were stronger than those obtained using the plasma T-tau test. The general findings of this study resonate well with two studies showing increased plasma P-tau concentration in $\mathrm{AD}$, as determined using immunomagnetic reduction technology [16] and Simoa [17], respectively.

\section{Plasma neurofilament light}

A well-replicated biomarker for neurodegeneration in $\mathrm{AD}$ is plasma neurofilament light (NfL), which is an intra-axonal structural protein that leaks into body fluids upon axonal injury irrespective of cause [18]. Serum or plasma levels of NfL (either matrix has good efficacy) correlate strongly with CSF NfL, are increased in several non-AD neurodegenerative diseases and are increased in both familial and sporadic $\mathrm{AD}$ [18]. In familial $\mathrm{AD}$, the levels increase in the time window around 10 years prior to expected clinical disease onset [19]; in sporadic disease the changes may appear slightly later and may also be influenced by age-related changes ( NfL concentration increase around $3 \%$ per year in CSF in normal aging [20]), or non-AD pathologies [21]. Altogether, plasma or serum NfL may be a reliable blood biomarker for neurodegeneration in $\mathrm{AD}$ and other neurodegenerative diseases.

\section{Panels of blood-based biomarkers Protein biomarker panels}

It has been suggested that panels of markers may outperform single candidate markers for diagnosing, prognosing and characterising AD [22]. Thus, a number of multivariate blood-based biomarker panels have been proposed for classifying the disease and its pathology. A large number of reports show efficacy of stratifying cases from controls using multivariate panels of protein markers. Ray et al. published one of the first of these studies, which identified 18 plasma proteins whose combined signature could distinguish $\mathrm{AD}$ patients from controls with $90 \%$ accuracy, as well as identify $\mathrm{MCI}$ patients who were at risk for progression to AD within five years [23]. The same group subsequently published results from independent samples detailing that many of the 18 proteins originally identified were also associated with CSF levels of $A \beta$ and tau [24]. However, other attempts to replicate the original findings have not been successful. Marksteiner and colleagues found that only five out of 16 of the original 18 markers had significantly different concentrations in $\mathrm{MCI}$ and $\mathrm{AD}$ patients vs. controls [25]. They found the sensitivity and specificity of the panel for identifying $\mathrm{AD}$ and $\mathrm{MCI}$ to be $65-75 \%$ and 
$52-63 \%$, respectively [25]. Similarly, Soares et al. found the diagnostic accuracy of the panel to be $60 \%$ [26], whilst Björkqvist et al. reported an area under the curve (AUC) of 63\% [27]. Soares et al., after failing to replicate efficacy in the Ray panel, proposed an alternative 89-analyte panel with a diagnostic accuracy of 70\% [26]. Subsequently, there have been numerous contributions of multivariate signatures for differentiating $\mathrm{AD}$ and/or MCI patients from controls [28-39], as well as a number of review articles [22, 40-43]. Two studies of most note include contributions by O'Bryant and colleagues [44] and Doecke and colleagues [45] who identified algorithmic signatures of multivariate analytes in large, well-characterised cohorts with AUC characteristics of at least $93 \%$ in serum and plasma, respectively. Doecke et al. also validated their signature in a second cohort with an AUC of 85\% [45]. Many of the analytes identified across these studies are related to amyloidosis and/ or inflammation, but still there has been a notable lack of harmonisation and replication of the findings. This is an area of research that has been much scrutinised, with a number of considerations and recommendations being made by O'Bryant and colleagues regarding study design, pre-analytical protocols and assay-related issues [46-49].

\section{Panels of blood-based biomarker-associated disease phenotypes}

Further to case-control studies, blood-based biomarker panels have been designed to estimate disease-related phenotypes, such as cognitive decline, brain atrophy and neocortical $A \beta$ deposition. Inflammatory markers [50-52], as well as proteins associated with the complement cascade [53], have reported associations with cognitive performance, cognitive decline and clinical progression. Most of these contributions also examined the association of proteomic signatures with brain volumetry finding similar signatures [50, 54-56]. Reports suggest that such signatures are able to explain approximately one third of the between subject variation observed in brain volumes $[54,57]$.

Blood biomarkers able to identify AD in its earliest stages are predicted to have the most impact for use as a screening tool. The early timing of abnormal levels of neocortical A $\beta$ deposition make it the 'gold standard' for early identification of disease, and therefore blood signatures associated with neocortical $\mathrm{A} \beta$ deposition have received considerable interest. Burnham et al. identified six plasma proteins that contributed to a signature that was able to estimate levels of neocortical $A \beta$ deposition in the AIBL cohort with a sensitivity and specificity of 80 and $82 \%$, respectively [58]. Validation of this signature in ADNI samples resulted in $79 \%$ sensitivity and $76 \%$ specificity [58]. The same group published follow-up results 54 months later, detailing the predictive ability of the same signature for identifying progression towards disease; cognitively normal individuals considered at risk by the signature progressed to $\mathrm{MCI}$ or $\mathrm{AD}$ with an odds ratio of 2.4 in comparison to those considered not at risk [59]. MCI participants considered at risk by the signature progressed to $\mathrm{AD}$ with an odds ratio of 12.3 in comparison to those considered not at risk [59]. Kiddle et al. similarly reported a signature that was associated with neocortical A $\beta$ deposition, identifying 13 markers which were able to explain over $30 \%$ of the between subject variation observed in neocortical $A \beta$ deposition [60]. Other studies with the same aim of inferring neocortical $A \beta$ deposition from a blood biomarker signature have reported efficacies of between 58 and 78\% [61-63]. A replication study by Voyle and colleagues found pancreatic polypeptide and IgM to correlate with neocortical $A \beta$ deposition, with IgM also correlating with neocortical $A \beta$ deposition within cognitively normal participants [63]. Again, the signatures across these contributions aligned with both inflammatory response and the complement cascade.

\section{Metabolomics}

Recent advances in nuclear magnetic resonance and mass spectroscopy, coupled with high performance liquid/gas chromatography have allowed the dynamic evaluation of thousands of metabolites, reflecting functional networks of downstream changes of the genome, transcriptome and proteome. Metabolic changes in plasma demonstrating a separation between controls and AD were reported by Greenberg et al. [64], with the two most influential metabolites being glycerophosphocholine and d-glucosaminide. Another contribution from Oresic et al. demonstrated metabolites that were differentially expressed in MCI participants who did and did not progress to $\mathrm{AD}$ within a 2-year time frame, with this finding being specifically driven by 2,4-dihydroxybutanoic acid [65]. Trushina and Mielke discuss results suggesting beta-alanine, aspartate and aspargine, alanine, l-cysteine, l-methionine, methionine-cysteine-glutamate, l-arginine, lysine and bile acid biosynthesis and metabolism were significantly different between controls and AD [66].

With links between cardiovascular disease and AD being drawn, as well as some promising results from lifestyle intervention on cognitive performance [67], lipid evaluation has become another area of interest in the search for blood-based biomarkers of AD. Two recent pilot studies have shown levels of lipids to differ significantly between mutation carriers and non-carriers in a study on familial AD [68], as well as AD and controls in a sporadic AD study [69]. However, neither study was able to use these profiles to accurately discriminate between the respective classes. Mapstone and colleagues were able to successfully discriminate AD from controls 
with $90 \%$ sensitivity and specificity in two separate studies. Firstly, using a panel of 10 lipids [70] and secondly with a panel of 22 lipids combined with an amino acid and a biogenic amine [71]. However, an independent group was unable to validate the findings from the 10-lipid panel in larger studies [72].

\section{miRNA biomarker panels}

Epigenetics are also of increasing interest to the field, with gene regulation by micro RNA (miRNA) representing one such focus for biomarker discovery. It is hypothesised that miRNAs are transported within liposomes, HDLs, exosomes and other proteins protecting the miRNA from degradation. Leidinger et al. first reported a panel of 12 miRNAs able to discriminate AD from controls with an accuracy of 93\% [73]. The panel also had the ability to discriminate AD patients from patients with $\mathrm{MCI}$, multiple sclerosis, parkinsonism, major depression, schizophrenia, and bipolar disorder with accuracies of 74-78\% [73]. Other studies identifying panels of miRNAs have been reported to discriminate between $\mathrm{AD}$ patients and controls with accuracies between 75 and $95 \%$ [74-76]. A recent review of miRNAs as biomarkers for $\mathrm{AD}$ is provided by Nagaraj and colleagues [77] where they report 136 individual miRNAs to be significantly altered between $\mathrm{AD}$ and control states from the literature. Of these 136 miRNAs, 36 were independently validated and reported in two or more contributions, with hsa-miR-125b being reported the most, 6, times.

\section{Exosomes}

This is a hot and controversial topic in the field of blood-based biomarkers for AD. Initial reports, in which neuronally derived exosomes were isolated from serum using antibodies against CNS-enriched antigens, lysed and analysed for AD-related biomarkers, showed promising results $[78,79]$, but the protocols are hard to follow and it is at the moment difficult to draw any strong conclusions on where this field is going.

\section{Future perspective}

As instruments for quantifying blood biomarkers become more sensitive and the understanding and implementation of standardisation procedures for sample processing and analysis are increased, the field moves ever closer to the quest for blood biomarkers in $\mathrm{AD}$. These improvements appear to have provided a shift in the most recent literature, away from multiplexed assays that were popular approximately 5 years ago, back full circle to single candidate markers that were also the focus of investigations $10-15$ years ago. The candidate markers showing the most promise as markers for $A D$ are plasma $A \beta 42 / A \beta 40$ ratio, tau and NfL but there is also promising data on new panels that may represent tissue responses to AD-related pathologies. However, replication and more detailed analyses are required to understand their merits as potential screening, diagnostic, prognostic or monitoring markers of the disease. An important goal will be to develop a screening/triage algorithm based on blood tests for $A \beta$ pathology and neurodegeneration that could be implemented in primary care settings and used for the effective identification of individuals who could be referred for further testing using CSF and PET markers and potential inclusion in clinical trials or future approved treatments. To validate such candidate algorithms, the AD biomarker research community needs to collaborate with primary healthcare specialists to establish new primary care-based cohorts that are evaluated using currently available gold standard measures of AD pathology (CSF and/or amyloid PET in specialised memory clinics) following application of the index test (the blood-based biomarker algorithm). When validated, such a diagnostic algorithm would facilitate $\mathrm{AD}$ drug development and prepare effective clinical pathways for the advent of disease-modifying therapies targeted against amyloid pathology.

\section{Abbreviations \\ AD: Alzheimer's disease; AUC: Area under the curve; A $\beta$ : Amyloid $\beta$; CSF: Cerebrospinal fluid; IP-MS: Immunoprecipitation mass spectrometry; MCl: Mild cognitive impairment; miRNA: Micro RNA; NfL: Neurofilament light; PET: Positron emission tomography; Simoa: Single molecule array}

\section{Acknowledgements}

Not applicable.

\section{Funding}

No specific funding was provided for writing this report but work in the authors' laboratories is supported by grants from the Swedish Research Council $(\mathrm{HZ})$, the European Research Council $(\mathrm{HZ})$, the Knut and Alice Wallenberg Foundation $(\mathrm{HZ})$, the Olav Thon Foundation $(\mathrm{HZ})$, the UK Dementia Research Institute at UCL $(\mathrm{HZ})$, the Australian National Health \& Medical Research Council (SB), the Australian Science and Industry Endowment Fund (SB), and the US National Institute of Health (SB).

\section{Availability of data and materials}

Data sharing not applicable to this article as no datasets were generated or analysed during the current study.

\section{Authors' contributions}

$\mathrm{HZ}$ and SB wrote the paper and approved the final manuscript.

Ethics approval and consent to participate Not applicable.

\section{Consent for publication}

Not applicable.

\section{Competing interests}

$\mathrm{HZ}$ has served at scientific advisory boards for Roche Diagnostics, Wave, Samumed and CogRx and is one of the founders of Brain Biomarker Solutions in Gothenburg AB, a GU Ventures-based platform company at the University of Gothenburg. SB reports no disclosures. 


\section{Publisher's Note}

Springer Nature remains neutral with regard to jurisdictional claims in published maps and institutional affiliations.

\section{Author details \\ ${ }^{1}$ Department of Psychiatry and Neurochemistry, Institute of Neuroscience and Physiology, he Sahlgrenska Academy at the University of Gothenburg, Mölndal, Sweden. ${ }^{2}$ Clinical Neurochemistry Laboratory, Sahlgrenska, University Hospital, Mölndal, Sweden. ${ }^{3}$ Department of Neurodegenerative Disease, UCL Queen Square Institute of Neurology, Queen Square, London, UK. ${ }^{4}$ UK Dementia Research Institute at UCL, London, UK. ${ }^{5} \mathrm{CSIRO}$ Health and Biosecurity, Parkville, Victoria 3052, Australia. ${ }^{6}$ Centre of Excellence for Alzheimer's Disease Research and Care, School of Medical and Health Sciences, Edith Cowan University, Joondalup, Western Australia 6027, Australia.}

\section{Received: 3 January 2019 Accepted: 15 March 2019}

Published online: 28 March 2019

\section{References}

1. Calderon-Garciduenas AL, Duyckaerts C. Alzheimer disease. Handb Clin Neurol. 2017:145:325-37.

2. Cohen AD, Landau SM, Snitz BE, Klunk WE, Blennow K, Zetterberg H. Fluid and PET biomarkers for amyloid pathology in Alzheimer's disease. Mol Cell Neurosci. 2018.

3. Scholl M, Maass A, Mattsson N, Ashton NJ, Blennow K, Zetterberg H, Jagust W. Biomarkers for tau pathology. Mol Cell Neurosci. 2018.

4. Olsson B, Lautner R, Andreasson U, Ohrfelt A, Portelius E, Bjerke M, Holtta M, Rosen C, Olsson C, Strobel G, et al. CSF and blood biomarkers for the diagnosis of Alzheimer's disease: a systematic review and meta-analysis. Lancet Neurol. 2016;15(7):673-84.

5. Zetterberg H, Mortberg E, Song L, Chang L, Provuncher GK, Patel PP, Ferrell E, Fournier DR, Kan CW, Campbell TG, et al. Hypoxia due to cardiac arrest induces a time-dependent increase in serum amyloid beta levels in humans. PLoS One. 2011;6(12):e28263.

6. Janelidze S, Stomrud E, Palmqvist $S$, Zetterberg $H$, van Westen D, Jeromin A, Song L, Hanlon D, Tan Hehir CA, Baker D, et al. Plasma beta-amyloid in Alzheimer's disease and vascular disease. Sci Rep. 2016;6:26801.

7. Verberk IMW, Slot RE, Verfaillie SCJ, Heijst H, Prins ND, van Berckel BNM, Scheltens P, Teunissen CE, van der Flier WM. Plasma amyloid as Prescreener for the earliest Alzheimer pathological changes. Ann Neurol. 2018;84(5):648-58.

8. Nakamura A, Kaneko N, Villemagne VL, Kato T, Doecke J, Dore V, Fowler C, Li QX, Martins R, Rowe C, et al. High performance plasma amyloid-beta biomarkers for Alzheimer's disease. Nature. 2018;554(7691):249-54.

9. Ovod V, Ramsey KN, Mawuenyega KG, Bollinger JG, Hicks T, Schneider T, Sullivan M, Paumier K, Holtzman DM, Morris JC, Benzinger T, Fagan AM, Patterson BW, Bateman RJ. Amyloid $\beta$ concentrations and stable isotope labeling kinetics of human plasma specific to central nervous system amyloidosis. Alzheimers Dement. 2017;13(8):841-49.

10. Li QX, Berndt MC, Bush Al, Rumble B, Mackenzie I, Friedhuber A, Beyreuther $\mathrm{K}$, Masters CL. Membrane-associated forms of the beta A4 amyloid protein precursor of Alzheimer's disease in human platelet and brain: surface expression on the activated human platelet. Blood. 1994;84(1):133-42.

11. Zetterberg H, Wilson D, Andreasson U, Minthon L, Blennow K, Randall J, Hansson O. Plasma tau levels in Alzheimer's disease. Alzheimers Res Ther. 2013:5(2):9.

12. Mattsson N, Zetterberg $H$, Janelidze $S$, Insel PS, Andreasson U, Stomrud E, Palmqvist S, Baker D, Tan Hehir CA, Jeromin A, et al. Plasma tau in Alzheimer disease. Neurology. 2016:87(17):1827-35.

13. Mielke MM, Hagen CE, Wennberg AMV, Airey DC, Savica R, Knopman DS, Machulda MM, Roberts RO, Jack CR Jr, Petersen RC, et al. Association of Plasma Total tau Level with Cognitive Decline and Risk of mild cognitive impairment or dementia in the Mayo Clinic study on aging. JAMA Neurol. 2017;74(9):1073-80.

14. Pase MP, Beiser AS, Himali JJ, Satizabal CL, Aparicio HJ, DeCarli C, Chêne G, Dufouil C, Seshadri S. Assessment of plasma Total tau level as a predictive biomarker for dementia and related Endophenotypes. JAMA Neurol. 2019. https://doi.org/10.1001/jamaneurol.2018.4666. [Epub ahead of print].

15. Mielke MM, Hagen CE, Xu J, Chai X, Vemuri P, Lowe VJ, Airey DC, Knopman DS, Roberts RO, Machulda MM, et al. Plasma phospho-tau181 increases with
Alzheimer's disease clinical severity and is associated with tau- and amyloidpositron emission tomography. Alzheimers Dement. 2018;14(8):989-97.

16. Yang CC, Chiu MJ, Chen TF, Chang HL, Liu BH, Yang SY. Assay of plasma phosphorylated tau protein (threonine 181) and Total tau protein in earlystage Alzheimer's disease. J Alzheimers Dis. 2018;61(4):1323-32.

17. Tatebe H, Kasai T, Ohmichi T, Kishi Y, Kakeya T, Waragai M, Kondo M, Allsop D, Tokuda T. Quantification of plasma phosphorylated tau to use as a biomarker for brain Alzheimer pathology: pilot case-control studies including patients with Alzheimer's disease and Down syndrome. Mol Neurodegener. 2017;12(1):63.

18. Khalil M, Teunissen CE, Otto M, Piehl F, Sormani MP, Gattringer T, Barro C, Kappos L, Comabella M, Fazekas F, et al. Neurofilaments as biomarkers in neurological disorders. Nat Rev Neurol. 2018;14(10):577-89.

19. Weston PSJ, Poole T, Ryan NS, Nair A, Liang Y, Macpherson K, Druyeh R, Malone IB, Ahsan RL, Pemberton $\mathrm{H}$, et al. Serum neurofilament light in familial Alzheimer disease: a marker of early neurodegeneration. Neurology. 2017:89(21):2167-75

20. Yilmaz A, Blennow K, Hagberg L, Nilsson S, Price RW, Schouten J, Spudich S, Underwood J, Zetterberg H, Gisslen M. Neurofilament light chain protein as a marker of neuronal injury: review of its use in HIV-1 infection and reference values for HIV-negative controls. Expert Rev Mol Diagn. 2017;17(8): 761-70.

21. Mattsson N, Andreasson U, Zetterberg H, Blennow K. Alzheimer's disease neuroimaging I: Association of Plasma Neurofilament Light with Neurodegeneration in patients with Alzheimer disease. JAMA Neurol. 2017; 74(5):557-66

22. Baird AL, Westwood S, Lovestone S. Blood-based proteomic biomarkers of Alzheimer's disease pathology. Front Neurol. 2015;6:236.

23. Ray S, Britschgi M, Herbert C, Takeda-Uchimura Y, Boxer A, Blennow K, Friedman LF, Galasko DR, Jutel M, Karydas A, et al. Classification and prediction of clinical Alzheimer's diagnosis based on plasma signaling proteins. Nat Med. 2007;13(11):1359-62.

24. Britschgi M, Rufibach K, Huang SL, Clark CM, Kaye JA, Li G, Peskind ER, Quinn JF, Galasko DR, Wyss-Coray T. Modeling of pathological traits in Alzheimer's disease based on systemic extracellular signaling proteome. Mol Cell Proteomics. 2011;10(10):M111 008862

25. Marksteiner J, Kemmler G, Weiss EM, Knaus G, Ullrich C, Mechtcheriakov S, Oberbauer $\mathrm{H}$, Auffinger $\mathrm{S}$, Hinterholzl J, Hinterhuber $\mathrm{H}$, et al. Five out of 16 plasma signaling proteins are enhanced in plasma of patients with mild cognitive impairment and Alzheimer's disease. Neurobiol Aging. 2011;32(3): 539-40.

26. Soares HD, Chen Y, Sabbagh M, Roher A, Schrijvers E, Breteler M. Identifying early markers of Alzheimer's disease using quantitative multiplex proteomic immunoassay panels. Ann N Y Acad Sci. 2009;1180:56-67.

27. Bjorkqvist M, Ohlsson M, Minthon L, Hansson O. Evaluation of a previously suggested plasma biomarker panel to identify Alzheimer's disease. PLoS One. 2012;7(1):e29868.

28. Hu WT, Holtzman DM, Fagan AM, Shaw LM, Perrin R, Arnold SE, Grossman M, Xiong C, Craig-Schapiro R, Clark CM, et al. Plasma multianalyte profiling in mild cognitive impairment and Alzheimer disease. Neurology. 2012;79(9): 897-905.

29. Laske C, Leyhe T, Stransky E, Hoffmann N, Fallgatter AJ, Dietzsch J. Identification of a blood-based biomarker panel for classification of Alzheimer's disease. Int J Neuropsychopharmacol. 2011;14(9):1147-55.

30. Guo LH, Alexopoulos P, Wagenpfeil S, Kurz A, Perneczky R. Alzheimer's disease neuroimaging I: plasma proteomics for the identification of Alzheimer disease. Alzheimer Dis Assoc Disord. 2013;27(4):337-42.

31. Llano DA, Devanarayan V, Simon AJ. Alzheimer's disease neuroimaging I: evaluation of plasma proteomic data for Alzheimer disease state classification and for the prediction of progression from mild cognitive impairment to Alzheimer disease. Alzheimer Dis Assoc Disord. 2013;27(3):233-43.

32. Zhang J, Jia J, Qin W, Wang S. Combination of plasma tumor necrosis factor receptors signaling proteins, beta-amyloid and apolipoprotein $\mathrm{E}$ for the detection of Alzheimer's disease. Neurosci Lett. 2013;541:99-104.

33. Agarwal $S$, Ghanty P, Pal NR. Identification of a small set of plasma signalling proteins using neural network for prediction of Alzheimer's disease. Bioinformatics. 2015;31(15):2505-13.

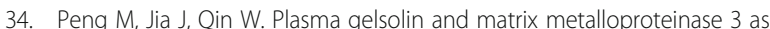
potential biomarkers for Alzheimer disease. Neurosci Lett. 2015;595:116-21.

35. Uchida K, Shan L, Suzuki H, Tabuse $Y$, Nishimura $Y$, Hirokawa $Y$, Mizukami K, Akatsu H, Meno K, Asada T. Amyloid-beta sequester 
proteins as blood-based biomarkers of cognitive decline. Alzheimers Dement (Amst). 2015;1(2):270-80.

36. Zhao X, Lejnine S, Spond J, Zhang C, Ramaraj TC, Holder DJ, Dai H, Weiner R, Laterza OF. A candidate plasma protein classifier to identify Alzheimer's disease. J Alzheimers Dis. 2015;43(2):549-63.

37. Johnstone D, Milward EA, Berretta R, Moscato P. Alzheimer's disease neuroimaging I: multivariate protein signatures of pre-clinical Alzheimer's disease in the Alzheimer's disease neuroimaging initiative (ADNI) plasma proteome dataset. PLoS One. 2012;7(4):e34341.

38. Olazaran J, Gil-de-Gomez L, Rodriguez-Martin A, Valenti-Soler M, Frades-Payo B, Marin-Munoz J, Antunez C, Frank-Garcia A, Acedo-Jimenez C, MorlanGracia $L$, et al. A blood-based, 7-metabolite signature for the early diagnosis of Alzheimer's disease. J Alzheimers Dis. 2015;45(4):1157-73.

39. Wang G, Zhou Y, Huang FJ, Tang HD, Xu XH, Liu JJ, Wang Y, Deng YL, Ren $\mathrm{RJ}, \mathrm{Xu}$ W, et al. Plasma metabolite profiles of Alzheimer's disease and mild cognitive impairment. J Proteome Res. 2014;13(5):2649-58.

40. Lista S, Faltraco F, Prvulovic D, Hampel H. Blood and plasma-based proteomic biomarker research in Alzheimer's disease. Prog Neurobiol. 2013;101-102:1-17.

41. Zurbig $P$, Jahn $\mathrm{H}$. Use of proteomic methods in the analysis of human body fluids in Alzheimer research. Electrophoresis. 2012;33(24):3617-30.

42. Shi L, Baird AL, Westwood S, Hye A, Dobson R, Thambisetty M, Lovestone S. A decade of blood biomarkers for Alzheimer's disease research: An evolving field, improving study designs, and the challenge of replication. J Alzheimers Dis. 2018;62(3):1181-98.

43. Jammeh E, Zhao P, Carroll C, Pearson S, Ifeachor E. Identification of blood biomarkers for use in point of care diagnosis tool for Alzheimer's disease. Conf Proc IEEE Eng Med Biol Soc. 2016;2016:2415-8.

44. O'Bryant SE, Xiao G, Barber R, Reisch J, Doody R, Fairchild T, Adams P, Waring S, Diaz-Arrastia R. Texas Alzheimer's research C: a serum proteinbased algorithm for the detection of Alzheimer disease. Arch Neurol. 2010; 67(9):1077-81

45. Doecke JD, Laws SM, Faux NG, Wilson W, Burnham SC, Lam CP, Mondal A, Bedo J, Bush Al, Brown B, et al. Blood-based protein biomarkers for diagnosis of Alzheimer disease. Arch Neurol. 2012;69(10):1318-25.

46. O'Bryant SE, Xiao G, Barber R, Huebinger R, Wilhelmsen K, Edwards M, GraffRadford N, Doody R, Diaz-Arrastia R, Texas Alzheimer's R, et al. A bloodbased screening tool for Alzheimer's disease that spans serum and plasma: findings from TARC and ADNI. PLoS One. 2011;6(12):e28092.

47. O'Bryant SE, Xiao G, Zhang F, Edwards M, German DC, Yin X, Como T, Reisch J, Huebinger RM, Graff-Radford N, et al. Validation of a serum screen for Alzheimer's disease across assay platforms, species, and tissues. J Alzheimers Dis. 2014;42(4):1325-35.

48. O'Bryant SE, Gupta V, Henriksen K, Edwards M, Jeromin A, Lista S, Bazenet C, Soares $\mathrm{H}$, Lovestone $\mathrm{S}$, Hampel $\mathrm{H}$, et al. Guidelines for the standardization of preanalytic variables for blood-based biomarker studies in Alzheimer's disease research. Alzheimers Dement. 2017;11(5):549-60.

49. O'Bryant SE, Mielke MM, Rissman RA, Lista S, Vanderstichele $H$, Zetterberg $H$, Lewczuk P, Posner H, Hall J, Johnson L, et al. Blood-based biomarkers in Alzheimer disease: current state of the science and a novel collaborative paradigm for advancing from discovery to clinic. Alzheimers Dement. 2017; 13(1):45-58.

50. Leung R, Proitsi P, Simmons A, Lunnon K, Guntert A, Kronenberg D, Pritchard M, Tsolaki M, Mecocci P, Kloszewska I, et al. Inflammatory proteins in plasma are associated with severity of Alzheimer's disease. PLoS One. 2013;8(6):e64971.

51. Popp J, Oikonomidi A, Tautvydaite D, Dayon L, Bacher M, Migliavacca E, Henry H, Kirkland R, Severin I, Wojcik J, et al. Markers of neuroinflammation associated with Alzheimer's disease pathology in older adults. Brain Behav Immun. 2017;62:203-11.

52. Hye A, Riddoch-Contreras J, Baird AL, Ashton NJ, Bazenet C, Leung R, Westman E, Simmons A, Dobson R, Sattlecker M, et al. Plasma proteins predict conversion to dementia from prodromal disease. Alzheimers Dement. 2014;10(6):799-807 e792.

53. Sattlecker M, Khondoker M, Proitsi P, Williams S, Soininen H, Kloszewska I, Mecocci P, Tsolaki M, Vellas B, Lovestone S, et al. Longitudinal protein changes in blood plasma associated with the rate of cognitive decline in Alzheimer's disease. J Alzheimers Dis. 2016;49(4):1105-14.

54. Thambisetty $M$, Simmons A, Hye A, Campbell J, Westman E, Zhang $Y$, Wahlund LO, Kinsey A, Causevic M, Killick R, et al. Plasma biomarkers of brain atrophy in Alzheimer's disease. PLoS One. 2011;6(12):e28527.

55. Toledo JB, Da X, Bhatt P, Wolk DA, Arnold SE, Shaw LM, Trojanowski JQ, Davatzikos C. Alzheimer's disease neuroimaging I: relationship between plasma analytes and SPARE-AD defined brain atrophy patterns in ADNI. PLoS One. 2013;8(2):e55531.

56. Jefferson AL, Massaro JM, Wolf PA, Seshadri S, Au R, Vasan RS, Larson MG, Meigs JB, Keaney JF Jr, Lipinska I, et al. Inflammatory biomarkers are associated with total brain volume: the Framingham heart study. Neurology. 2007:68(13):1032-8.

57. Thambisetty M, Simmons A, Velayudhan L, Hye A, Campbell J, Zhang Y, Wahlund LO, Westman E, Kinsey A, Guntert A, et al. Association of plasma clusterin concentration with severity, pathology, and progression in Alzheimer disease. Arch Gen Psychiatry. 2010;67(7):739-48.

58. Burnham SC, Faux NG, Wilson W, Laws SM, Ames D, Bedo J, Bush Al, Doecke JD, Ellis KA, Head R, et al. A blood-based predictor for neocortical Abeta burden in Alzheimer's disease: results from the AIBL study. Mol Psychiatry. 2014;19(4):519-26.

59. Burnham SC, Rowe CC, Baker D, Bush Al, Doecke JD, Faux NG, Laws SM, Martins RN, Maruff P, Macaulay SL, et al. Predicting Alzheimer disease from a blood-based biomarker profile: a 54-month follow-up. Neurology. 2016; 87(11):1093-101.

60. Kiddle SJ, Thambisetty M, Simmons A, Riddoch-Contreras J, Hye A, Westman E, Pike I, Ward M, Johnston C, Lupton MK, et al. Plasma based markers of [11C] PiB-PET brain amyloid burden. PLoS One. 2012;7(9):e44260.

61. Ashton NJ, Kiddle SJ, Graf J, Ward M, Baird AL, Hye A, Westwood S, Wong $\mathrm{KV}$, Dobson RJ, Rabinovici GD, et al. Blood protein predictors of brain amyloid for enrichment in clinical trials? Alzheimers Dement (Amst). 2015; 1(1):48-60.

62. Apostolova LG, Hwang KS, Avila D, Elashoff D, Kohannim O, Teng E, Sokolow S, Jack CR, Jagust WJ, Shaw L, et al. Brain amyloidosis ascertainment from cognitive, imaging, and peripheral blood protein measures. Neurology. 2015;84(7):729-37.

63. Voyle N, Baker D, Burnham SC, Covin A, Zhang Z, Sangurdekar DP, Tan Hehir CA, Bazenet C, Lovestone S, Kiddle S, et al. Blood protein markers of neocortical amyloid-beta burden: a candidate study using SOMAscan technology. J Alzheimers Dis. 2015;46(4):947-61.

64. Greenberg N, Grassano A, Thambisetty M, Lovestone S, Legido-Quigley C. A proposed metabolic strategy for monitoring disease progression in Alzheimer's disease. Electrophoresis. 2009;30(7):1235-9.

65. Oresic M, Hyotylainen T, Herukka SK, Sysi-Aho M, Mattila I, Seppanan-Laakso T, Julkunen V, Gopalacharyulu PV, Hallikainen M, Koikkalainen J, et al. Metabolome in progression to Alzheimer's disease. Transl Psychiatry. 2011;1:e57.

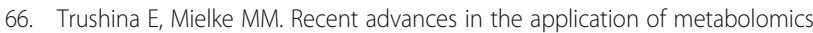
to Alzheimer's disease. Biochim Biophys Acta. 2014;1842(8):1232-9.

67. Kivipelto M, Mangialasche F, Ngandu T. Lifestyle interventions to prevent cognitive impairment, dementia and Alzheimer disease. Nat Rev Neurol. 2018;14(11):653-66.

68. Chatterjee P, Lim WL, Shui G, Gupta VB, James I, Fagan AM, Xiong C, Sohrabi HR, Taddei K, Brown BM, et al. Plasma phospholipid and sphingolipid alterations in Presenilin1 mutation carriers: a pilot study. J Alzheimers Dis. 2016;50(3):887-94.

69. Costa AC, Joaquim HPG, Forlenza O, Talib LL, Gattaz WF. Plasma lipids metabolism in mild cognitive impairment and Alzheimer's disease. World J Biol Psychiatry. 2017:9:1-7.

70. Mapstone M, Cheema AK, Fiandaca MS, Zhong X, Mhyre TR, MacArthur LH, Hall WJ, Fisher SG, Peterson DR, Haley JM, et al. Plasma phospholipids identify antecedent memory impairment in older adults. Nat Med. 2014 20(4):415-8.

71. Fiandaca MS, Zhong $X$, Cheema AK, Orquiza MH, Chidambaram S, Tan MT, Gresenz CR, FitzGerald KT, Nalls MA, Singleton AB, et al. Plasma 24metabolite panel predicts preclinical transition to clinical stages of Alzheimer's disease. Front Neurol. 2015;6:237.

72. Casanova R, Varma S, Simpson B, Kim M, An Y, Saldana S, Riveros C, Moscato P, Griswold M, Sonntag D, et al. Blood metabolite markers of preclinical Alzheimer's disease in two longitudinally followed cohorts of older individuals. Alzheimers Dement. 2016;12(7):815-22.

73. Leidinger P, Backes C, Deutscher S, Schmitt K, Mueller SC, Frese K, Haas J, Ruprecht K, Paul F, Stahler C, et al. A blood based 12-miRNA signature of Alzheimer disease patients. Genome Biol. 2013;14(7):R78.

74. Zendjabil M. Circulating microRNAs as novel biomarkers of Alzheimer's disease. Clin Chim Acta. 2018:484:99-104.

75. Cheng L, Doecke JD, Sharples RA, Villemagne VL, Fowler CJ, Rembach A, Martins RN, Rowe CC, Macaulay SL, Masters CL, et al. Prognostic serum miRNA biomarkers associated with Alzheimer's disease shows concordance 
with neuropsychological and neuroimaging assessment. Mol Psychiatry. 2015;20(10):1188-96.

76. Nagaraj S, Laskowska-Kaszub K, Debski KJ, Wojsiat J, Dabrowski M, Gabryelewicz T, Kuznicki J, Wojda U. Profile of 6 microRNA in blood plasma distinguish early stage Alzheimer's disease patients from non-demented subjects. Oncotarget. 2017:8(10):16122-43.

77. Nagaraj S, Zoltowska KM, Laskowska-Kaszub K, Wojda U. microRNA diagnostic panel for Alzheimer's disease and epigenetic trade-off between neurodegeneration and cancer. Ageing Res Rev. 2019;49:125-43.

78. Fiandaca MS, Kapogiannis D, Mapstone M, Boxer A, Eitan E, Schwartz JB, Abner EL, Petersen RC, Federoff HJ, Miller BL, et al. Identification of preclinical Alzheimer's disease by a profile of pathogenic proteins in neurally derived blood exosomes: a case-control study. Alzheimers Dement. 2015;11(6):600-7 e601.

79. Goetzl EJ, Boxer A, Schwartz JB, Abner EL, Petersen RC, Miller BL, Kapogiannis D. Altered lysosomal proteins in neural-derived plasma exosomes in preclinical Alzheimer disease. Neurology. 2015;85(1):40-7.

Ready to submit your research? Choose BMC and benefit from:

- fast, convenient online submission

- thorough peer review by experienced researchers in your field

- rapid publication on acceptance

- support for research data, including large and complex data types

- gold Open Access which fosters wider collaboration and increased citations

- maximum visibility for your research: over $100 \mathrm{M}$ website views per year

At $\mathrm{BMC}$, research is always in progress.

Learn more biomedcentral.com/submissions 